\title{
Geo-mechanics and Hydraulic Conductivity Study of Claystone in Boyolali, Central Java, Indonesia
}

\author{
Wawan Budianta*1 ${ }^{*}$ Monika Aprianti Popang ${ }^{2}$, Widyawanto Prastistho ${ }^{1}$, Jiro Takemura ${ }^{2}$, \\ and Hirofumi Hinode ${ }^{2}$ \\ ${ }^{1}$ Department of Geological Engineering, Faculty of Engineering, Universitas Gadjah Mada, Yogyakarta, Indonesia \\ ${ }^{2}$ Tokyo Institute of Technology, Japan
}

\begin{abstract}
Claystone middle Miocene age were found in Wonosegoro sub-district, Boyolali region, Central Java, Indonesia. The purpose of the paper is to examine and discuss the geology and typical behavor of this claystone and its micro-level mechanism. The hydraulic conductivity was assessed using consilidated apparatuses; $150 \mathrm{~mm}$ diameter column mound using aggregated sample and $60 \mathrm{~mm}$ oedometer mould using slurry sample as a reference. Claystone materials used were treated under various conditions. In long term test under constand vertical stress and hydraulic gradient, the hydraulic conductvity decreases with time although the volume of void volume of the sample increased by swelling. Water contens of the individul aggregated increased by swelling, by which strength of particles decreases with and aggregate breakdown was enchanced. As a result, large void created by large particles could be redused in its size, leading the reduction of hydraulic conductuvity. The hydralic conductivities ( $K$ values) obtained from the aggregated sample varied in a broad range compared with those from slurry sample. In the test using the higher percentage of gravel-sized aggregate (up until couarse gravel-sized; retained in $26.5 \mathrm{~mm}$ sieve), $K$ values changed from $10^{-5}$ to $10^{-7} \mathrm{~m} / \mathrm{s}$ under vertical stresses from 5 up to $245 \mathrm{kPa}$. The test was repeated using smaller percentage of gravel-sized aggregate (up until fine gravel-sized, retained in $4.75 \mathrm{~mm}$ sieve) and the observed $K$ values changed from $10^{-5}$ to $10^{-10} \mathrm{~m} / \mathrm{s}$. While the $\mathrm{K}$ values obtained in the specimen made from surry under same vertical stresses was $10^{-9}$ to $10^{-11} \mathrm{~m} / \mathrm{s}$. All of the extruded aggregate samples had higher water content than the initial ones, which suggest the alteration mechanism of soled consolidation phase to more deformable plastic phase, whice enables the sample to decrease the void size. These results conclude that using coarse gravel-sized aggregated, which is a reasonable scenario of a practically feasible aggregate size in a field, may noy produce the aimed hydraulic conductivity by the regulated standard. Therefore, breakdown of the aggrgate size and enchament of swelling are crucial factors for the application of the clay stones as a barrier material.
\end{abstract}

Keywords: Hydraulic conductivity · Initial water content · Swelling · WonosegoroBoyolali claystone.

\section{INTRODUCTION}

The Claystone deposit were found in Wonosegoro sub-district, Boyolali region, Central Java, Indonesia. The existing conditon

\footnotetext{
${ }^{*}$ Corresponding author: W. BUDIANTA, Department of Geological Engineering, Universitas Gadjah Mada. Jl. Grafika 2 Yogyakarta, Indonesia. E-mail: wbudianta@ugm.ac.id
}

of this clay deposit is a massive sedimentary structure which makes both exploration and usage interest of this material a bit complicated. The alteration of solid consolidated phase to plastic phase is necessary to guaranted the workability of material, and most importantly, the hydraulic conductivity performance of the barrier as regulated. Usually, the deterioration, 
or disintergration, or any other terms under same concept of clay-bearing stone are demerit to a common soil structure, but in this case, the disentegration of claystone is encouraged. The objective of this study, is to geologically evaluate and to examine and discuss the typical behavor of this claystone and its micro-level mechanism. Wonosegoro sub-district, Boyolali region, Central Java, Indonesia may be considered as a major source for claystone deposits which show a large distribution (Budianta et al., 2014). These deposits are rich in clay minerals (such as smectite, illite, chlorite and kaolinite), which makes these deposits an invaluable material for engineering barrier material ( $\mathrm{Yu}-$ lianti et al., 2011; Pratistho, 2014). To determine the hydraulic conductivity of the WonosegoroBoyolali claystone in Boyolali, two claystones sampling sites have been selected (Figure 1). The first site is in Garangan Village site and claystone sampling has been performed at the excavation site of the residential building (BL Sample). The second site is in Bandung Village where clay samples has been collected from the river bed of Bandung river (GR Sample). Some view of lithology in study area are shown in Figure 1. It shown that the claystose has dark green color with the high degree of dip.

\section{Material and Methodology}

There are two clusters of sample which have been collected upon testing. BL sample was collected from fist unit located in riverbed area which has more exposure to weathering, while GR sample was collected from second unit located in cliffside area which has less exposure to weathering. The soil particle size distribution, specific gravity of the solids, and Atterberg limits, specifically the liquid limit (LL), plastic limit (PL) and plasticity index (PI) were determined according to standard practice (ASTM D422-63 (2002), D854-02 and D4318-00). The liquid limit (LL) and plasticity index (PI) values were used for classifying the clayey soil samples according to the Unified Soil Classification System (USCS; ASTM D2487-00). The results presented in Figure 4 show that the GR sample is classified as $\mathrm{CH}$ (fat clay with sand) and that BL sample as CL (sandy lean clay). Intrinsic properties of BL and GR samples were ob-
Table 1: Intrinsic and intact properties of claystones.

\begin{tabular}{|c|c|c|}
\hline Properties & BL & GR \\
\hline \multicolumn{3}{|c|}{ Intrinsic properties obtained from the slurry clay } \\
\hline Liquid Limit, $L L$ & $56.50 \%$ & $57.81 \%$ \\
\hline Plastic Limit, PL & $33.59 \%$ & $28.32 \%$ \\
\hline Shrinkage Limit, SL & $24.24 \%$ & $19.30 \%$ \\
\hline Specific Gravity, GS & 2.72 & 2.69 \\
\hline \multicolumn{3}{|c|}{ Intact properties of the claystone } \\
\hline Water Content, wc & $8.43 \%$ & $16.04 \%$ \\
\hline Void Ratio, e & 0.36 & 0.63 \\
\hline Porosity, $\mathrm{n}$ & 0.26 & 0.39 \\
\hline Degree of Saturation, SR & $62.68 \%$ & $68.62 \%$ \\
\hline
\end{tabular}

tained from the slurry-made of clay sample and presented in Table 1.

Representative intact properties of the clay samples sare also included in the table to provide general understanding in regards to the initial field conditions of the samples. In this work, two types of apparatus were used for hydraulic conductivity ( $K$ value) measurement. The first apparatus was a regular oedometer mold $(60 \mathrm{~mm}$ in diameter and $20 \mathrm{~mm}$ in thickness) with attachment of $5 \mathrm{~mm}$ diameterst and pipe at the bottom drainage, enables to conduct falling head permeability test. In order to accommodate relatively large-sized aggregates of the clay sample during testing, $150 \mathrm{~mm}$ diameter column mold was also used in this test. The hydraulic conductivity of the sample was measure by seepage via the bottom drainage valve under a constant head condition (Figure 2). Samples were treated under various conditions. Table 2 shows the conditions of each case conducted in this experiment. First two of characters denote type of clay sample and last two characters denote type of mold were used in the test. Slurry sample was made from crushed clay samples. Foremost, excessively large gravelsized claystone was crushed using hammer. Eventually, the smaller sized aggregate was put into mortar for further crushing by pestle until finer sized aggregate was formed. Fine-sized aggregates were mixed carefully with tap water around 1.5 times Liquid Limit $\left(w_{L L}\right)$ then deaired using vacuum device for a while. Afterwards, slurry-made claystone was inserted into the oedometer mold for preconsolidation stage. 

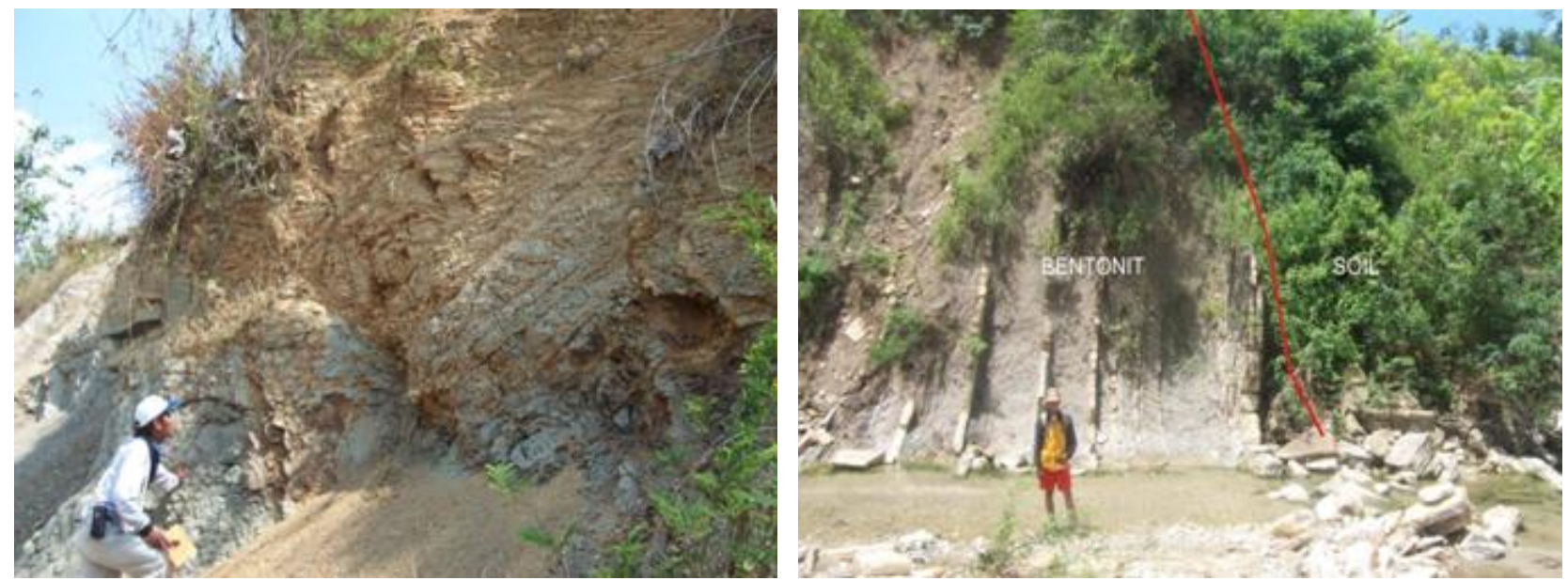

Figure 1: A general view of Boyolali Clay at the sampling location.

Table 2: Summary of test conditions.

\begin{tabular}{|l|c|c|c|c|}
\hline Tests Cases & Sample Condition & Testing Apparatus & $\begin{array}{c}\text { Water } \\
\text { Content }\end{array}$ & $\begin{array}{c}\text { Liquidity } \\
\text { Index }\end{array}$ \\
\hline Case BLO1 & Slurry-made Sample & Oedometer Mold & $64 \%$ & 1.33 \\
\hline Case GRO2 & Slurry-made Sample & Oedometer Mold & $55 \%$ & 0.90 \\
\hline Case BLO3 & $\begin{array}{c}\text { Aggregated Dry } \\
\text { (graded-size) }\end{array}$ & Oedometer Mold & $12 \%$ & -0.94 \\
\hline Case BLO4 & Remolded Sample & Oedometer Mold & $40 \%$ & 0.28 \\
\hline Case GRO5 & Remolded Sample & Oedometer Mold & $43 \%$ & 0.50 \\
\hline Case BLO6 & $\begin{array}{c}\text { Aggregated Wet } \\
\text { (uniform-size) }\end{array}$ & Oedometer Mold & $32 \%$ & -0.07 \\
\hline Case GRO7 & $\begin{array}{c}\text { Aggregated Wet } \\
\text { (uniform-size) }\end{array}$ & Oedometer Mold & $27 \%$ & -0.04 \\
\hline Case BLC1 & Aggregated Dry & Column Mold $\left(h_{\text {init }}=7.5 \mathrm{~cm}\right)$ & $12 \%$ & -0.94 \\
\hline Case BLC2 & Aggregated Wet & Column Mold $\left(h_{\text {init }}=9 \mathrm{~cm}\right)$ & $29 \%$ & -0.20 \\
\hline Case GRC3 & Aggregated Dry & Column Mold $\left(h_{\text {init }}=13 \mathrm{~cm}\right)$ & $10 \%$ & -0.62 \\
\hline Case GRC4 & Aggregated Wet & Column Mold $\left(h_{\text {init }}=12 \mathrm{~cm}\right)$ & $25 \%$ & -0.11 \\
\hline Case GRC5 & Aggregated Wet & Column Mold $\left(h_{\text {init }}=10 \mathrm{~cm}\right)$ & $35 \%$ & 0.23 \\
\hline
\end{tabular}




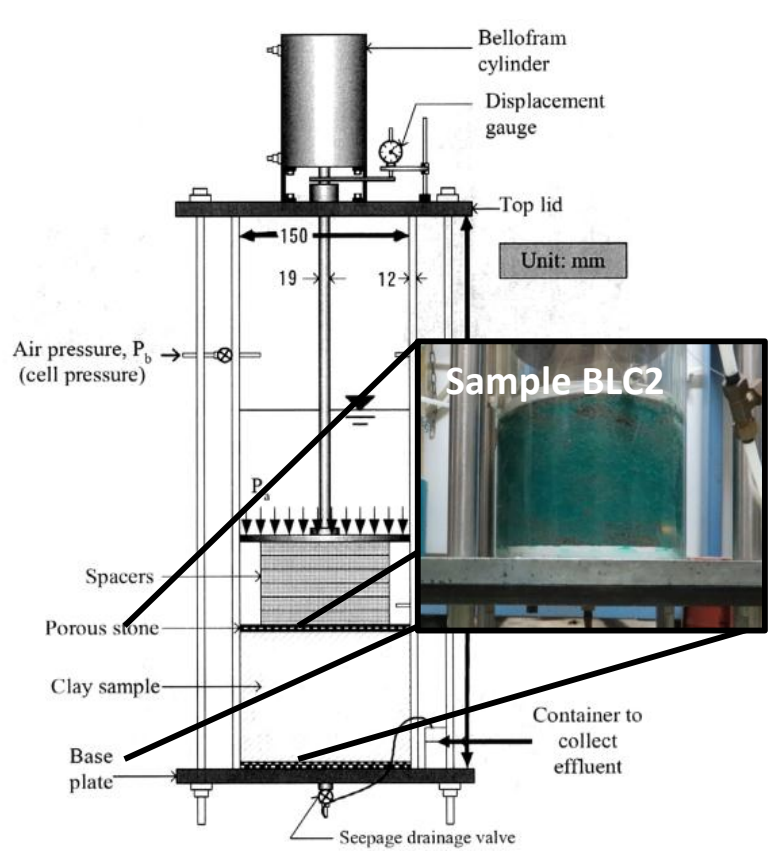

Figure 2: Schematic View of Column Mold Test Apparatus (Tanchuling et al., 2006) and Utilized Sample.

Before preconsolidation stage stage, the inner wall of the oedometer mold was coated with silicon grease to impede sidewall leakage. Slurry sample was then preconsolidated with preconsolidation pressure $\left(p^{\prime}\right)$ of $20 \mathrm{kPa}$. Remolded sample was also prepared using same method with slurry-made sample, but mixed with less water until it reached cake-like consistency. Remolded sample then preconsolidated with preconsolidation pressure of $80 \mathrm{kPa}$. After the preconsolidation stage, the mold is dismantled to trim the excess soil for water content measurement. Lastly, loading cap and dial gauge was mounted back to the mold. The incremental loading consolidation test was conducted under single drainage consolidation with the load increment ratio (LIR) of 1 from the pressure $(p)$ of $10 \mathrm{kPa}$ to $1280 \mathrm{kPa}$. Then swelling tests were done by decreasing the pressure with LIR of 2 until $20 \mathrm{kPa}$. Hydraulic conductivity measurement was done by the falling head method after the completion of primary consolidation for about 20 hours. While for preparing the aggregated sample, excessively large aggregates were eliminated by crushing using hammer in order to be fit onto the column mold. Afterwards, the sample was sieved prior to testing (Figure 3).

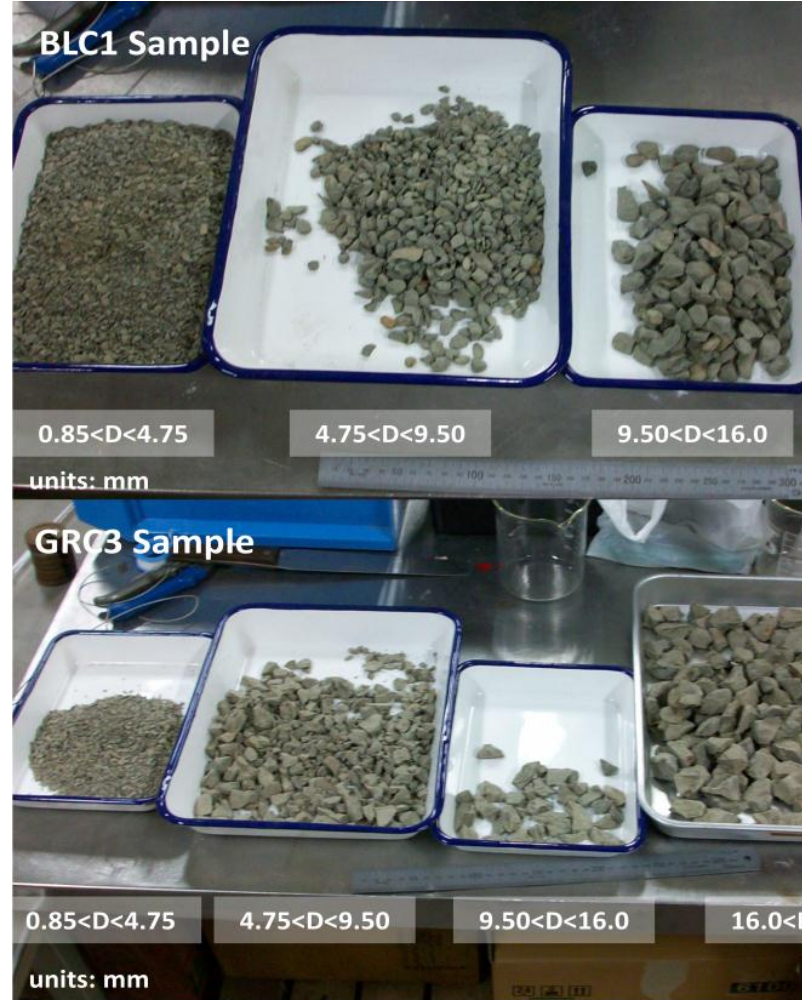

Figure 3: Photographic view of aggregated dry sample for column test.

In this study, the largest size of aggregate sample used was around $26.5 \mathrm{~mm}$, meanwhile aggregate size distributions of all test cases using aggregated samples are as illustrated in Figure 4. After sieving and measuring its initial water contents, the aggregates were mixed together and then carefully placed into the column mold. To avoid the side wall leakage, large amount of silicone grease was smeared on the inner surface of the mold (Figure 4). After placing the sample in the mold, the filter paper, porous stone disk, perforated loading plate, bellofram cylinder, and dial gauge were respectively inserted onto the column mold. To increase the degree of saturation (SR) of the column sample, $\mathrm{CO}_{2}$ gas was first injected from the bottom and then de-aired water was slowly supplied from the bottom. Upon testing, the vertical load $(p)$ was applied by bellofram cylinderfrom $10 \mathrm{kPa}$ up to $\pm 245 \mathrm{kPa}$. Each load was kept one day and the hydraulic conductivity was determined by measuring the discharge water rate under a constant head difference $(h)$ of about $0.31 \mathrm{~m}$ at the beginning of the each loading and the end of the loading. After the consolidation at the maximum pressure, 


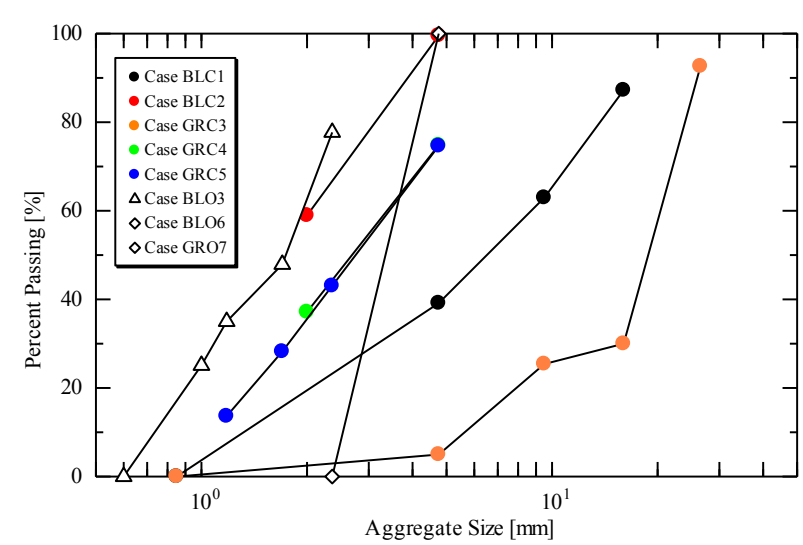

Figure 4: Aggregate distribution size for all aggregated sample.

the load was then reduced stepwise. Especially at case BLC1, the variations of $K$ values were measured for approximately one month under low pressure of $\pm 2 \mathrm{kPa}$. After the test using the dry intact aggregates (Cases BLC1 and GRC3) finishes, the samples were extruded from the mold and the final water contents were measured. The extruded sample was disintegrated to the aggregates and used for the further column tests after carefully disposing the soil that has been contaminated with silicone grease.

\section{Results AND Discussion}

\subsection{Geology and mineralogy of Wonosegoro- Boyolali claystone}

Volcanic clastics of Miocene age and Quaternary alluvial deposits fill the Kendeng basin, which was an anticlinorium zone which was a fold-thrust belt that has margin to quaternary volcanic arc separated by Ngawi subzone alluvial (van Bemmelen, 1949). van Bemmelen (1949) called the lithology of study area as Kerek Formation, and he studied the geological characteristics of this sediment characterized by intercalation of claystone, calcareous claystone, marl, calcareous tuffaceous sandstone and tuffaceous sandstone. The claystone deposit in study area was belongs to Kerek Formation that have middle Miocene age and had been deposited in marine environment (inner middle neritic zone) by turbidity current mechanism, whereas clay - gravel unit is in quartenary age river deposit.

Several folds associate with reverse faults were the dominant geological structures in this study area. The fold was often plunged and has eastwest orientation. Similar with the folds, reverse fault found associated with fold also in the same orientation. These geological structures are formed by relatively north-south compression (van Bemmelen, 1949). The clay mineral assemblage contained in these deposit was dominated mainly by Ca-montmorillonite, kaolinite, illite, zeolite (heulandite, mordenite), quartz, plagioclase, potassium feldspar (ortoclase and sanidine), calcite and magnetite (Yulianti et al., 2011; Pratistho, 2014). Geological map of study area was shown in Figure 5. The area consist of three geological unit, named claystone intercalation with sandstone unit, claystone interbedded with sandstone unit and alluvial deposit unit. The BL sample afrementioned was located in claystone intercallation with sandstone unit and GR sample was obtained form claystone interbedded with sandstone unit, as shown in Figure 5.

Stratigraphic columnar section of the study area can bee seen in Figure 6, showed that the oldest lithology was claystone intercallation with sandstone unit containing dark green claystone with carbonate material, massive brownish sandstone with carbonate cement and dark green claystone with convulute laminated brownish sandstone with carbonate cement. The younger lithology deposited was claystone interbedded with sandstone unit containing dark green claystone with convulute laminated brownish sandstone with carbonate cement and massive brownish sandstone with carbonate cement. The youngest lithology was alluvial deposit containing loose material of gravel, sand, silt and clay.

\subsection{Compresibility and void ratio of test samples}

Variation of void ratio (e) with vertical consolidation pressure $(p)$ relation is shown as $e-\log$ $p$ form in Figure 7. The void ratio and compressibility of the samples were highly dependent on the initial conditions (see Table 2). Test cases with aggregated samples were more deformable hence has wider range of void ratio compared to those of slurry and remolded samples. For dry aggregated samples, the typical e-log $p$ obtained from any test has unsteady change, which could be attributed to particle crushing. This deformability could be caused by large inter-aggregate pore that trig- 


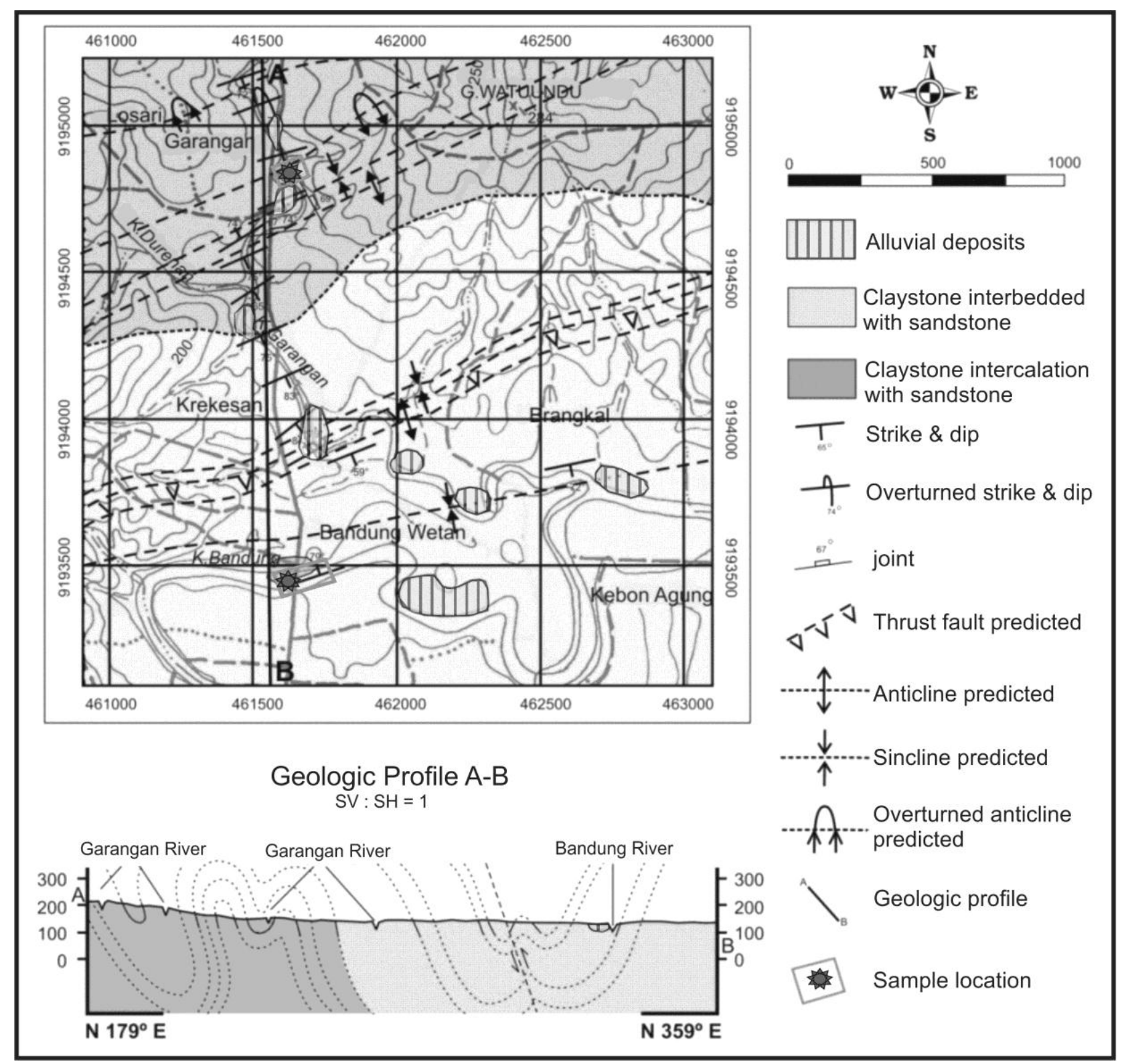

Figure 5: Geological map of the study area. 


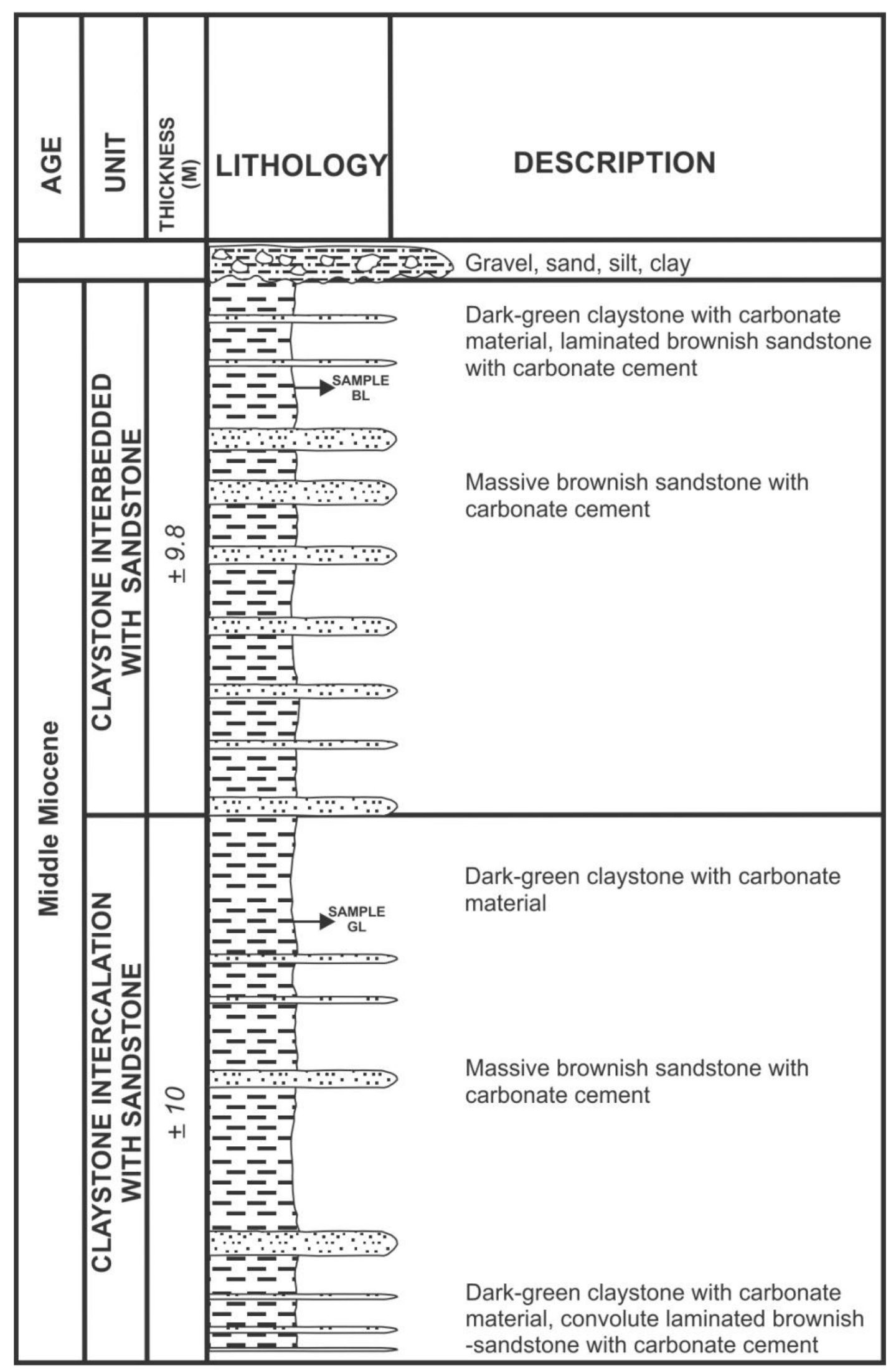

Figure 6: Stratigraphic columnar section of the study area. 


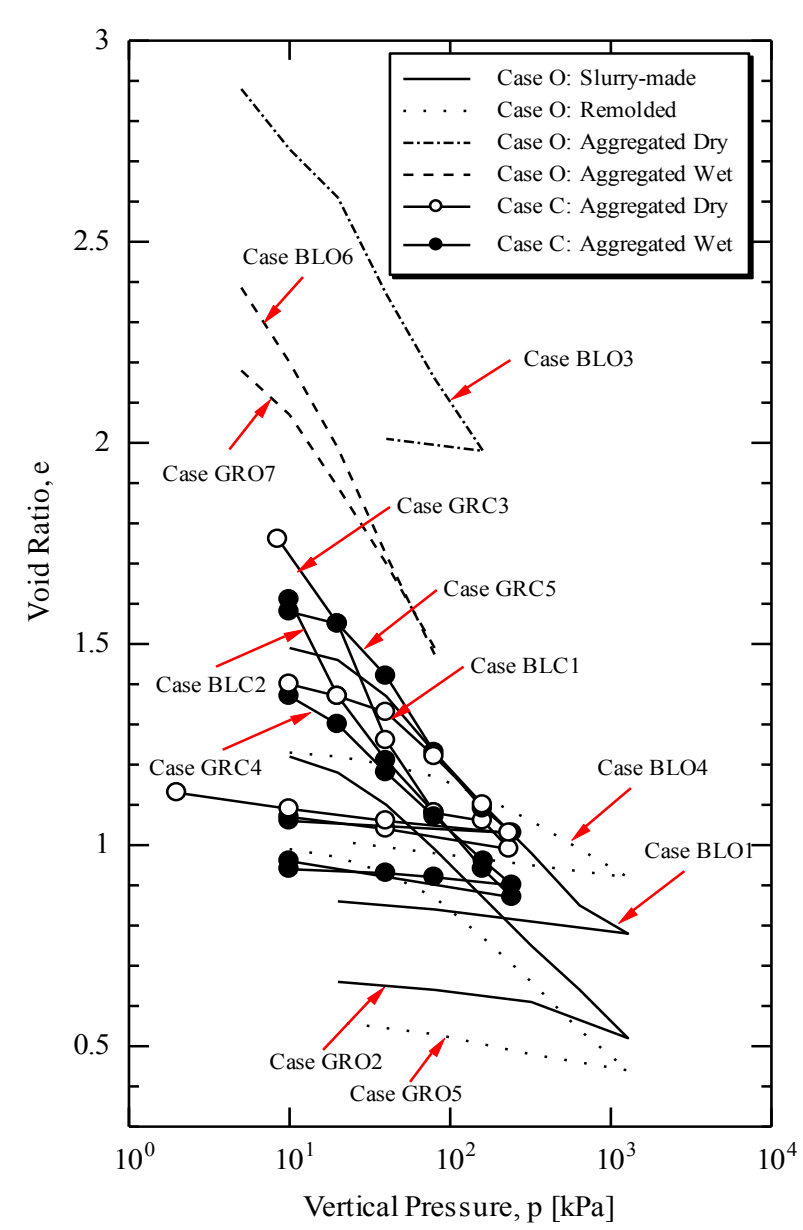

Figure 7: Overall $e$ - $\log p$ results.

gers "instable interlocking" within aggregates and undergo crushing process until it reaches "stable interlocking" condition. This prone-todeform condition might be observed in the uniform-sized sample (Case BLO6 and GRO7) and gap-graded sample (Case GRC3).

\subsection{Hydraulic conductivity of slurry-made and remolded samples}

Hydraulic conductivity obtained from the slurry made sample were taken as a reference of minimum hydraulic conductivity achievable for this type of material. Figure 8 shows a timevariation of observed Kvalues in the falling head permeameterfor a slurry-made sample. The $\mathrm{K}$ values decreased with time to converge a constant value, whichwas taken as the representative value for each loading condition. The $K$ values are plotted against void ratio in Figure 7. The results of unloading stages are not included in the figure, because of errors due to the side-wall leakage.

The slurry-made samples yield significantly

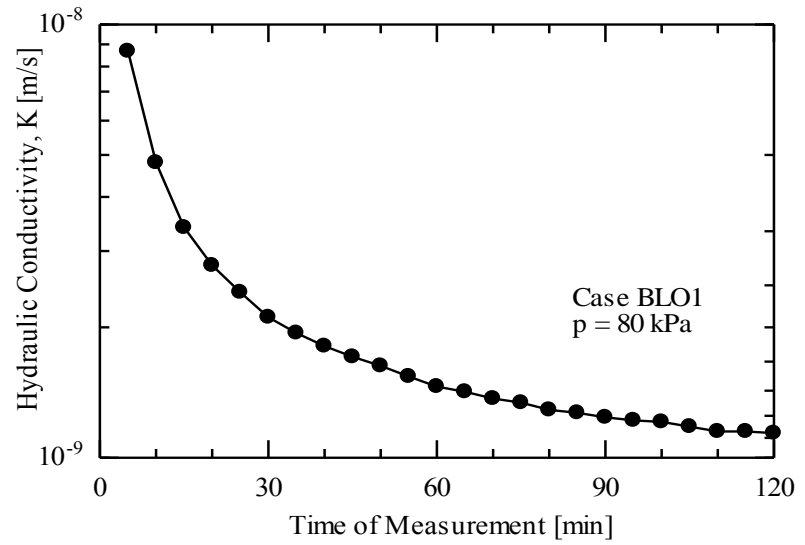

Figure 8: Typical hydraulic conductivity obtained of slurry-made sample.

lower $K$ values of $10^{-9} \mathrm{~m} / \mathrm{s}$ to $10^{-10} \mathrm{~m} / \mathrm{s}$ compared to the aggregated sample atthe same void ratio (e), because of inter-aggregate poresof the aggregated sample are significantly larger. A slight discrepancy between Case GRO2 and Case BLO1 was also observed, implying the effect of weathering level of the two claystones.

\subsection{Hydraulic conductivity of aggregated samples}

The $K$ values obtained from the aggregated samplesare also shown in Figure 9. Overall range of $K$ values isfrom $10^{-5} \mathrm{~m} / \mathrm{s}$ to $10^{-10} \mathrm{~m} / \mathrm{s}$ showing the wide variation. It also can be observed that from the cases which were tested at dry condition and higher fraction of largesized aggregates will generate higher $K$ values (Case BLC1 and GRC3) compared to those with higher water content and less gravel size fraction at the same void ratio (Case BLC2, GRC4, and GRC5). All case BLC1, BLC2, GRC4, and GRC5 have desired linear trends. Meanwhile, all case GRC3, BLO3, BLO6, and GRO7 have typical arched trends. These aforementioned cases have least range of $K$ values compared to the others, despite the wide range of compression. This is as result of continuous disintegration of dry large aggregate as load was applied as explained at previous section. During this stage, disintegration of the aggregate is prominent hence $K$ value seems to have unsteady change because of the change of void volume. This effect, as illustrated in Figure 7, could yield different results especially at early loading stage. The results obtained from this section suggest the importance of initial wa- 


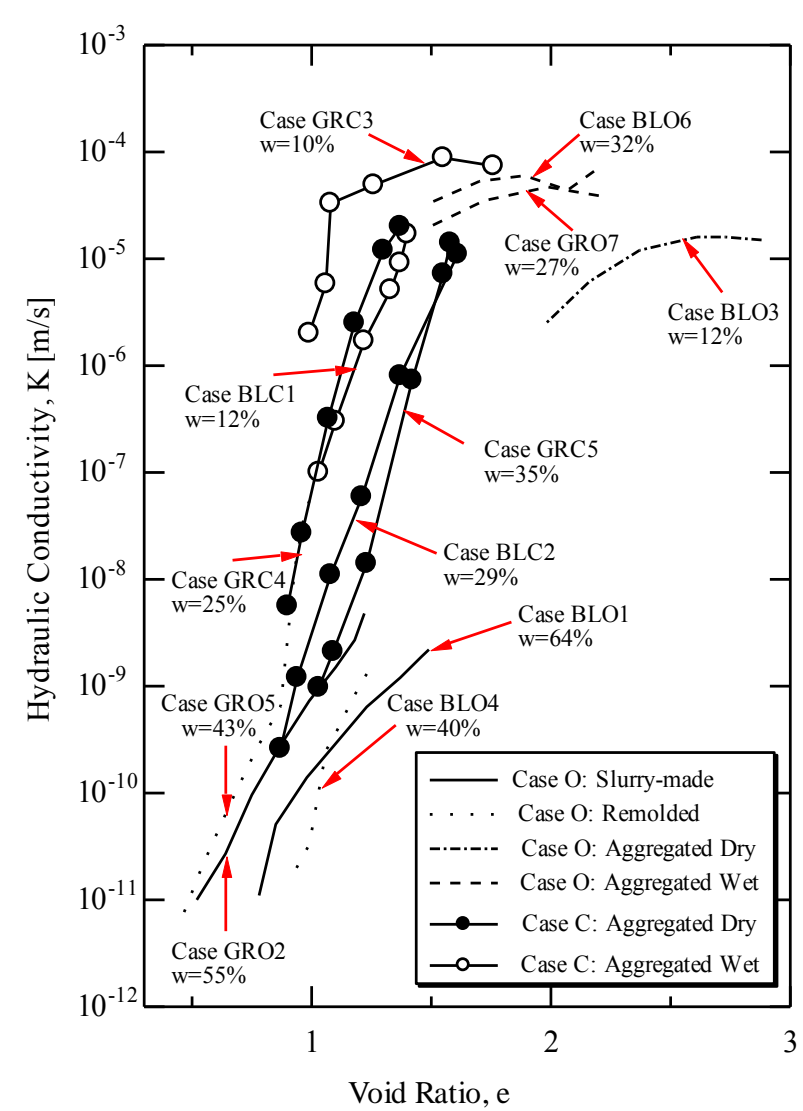

Figure 9: Overall hydraulic conductivity measurement results

ter content and initial aggregate size gradation among other mechanisms that also were observed throughout the experiment.

\subsection{Effect of swelling and initial water con- tent}

In order to discuss the effect of swelling, the results of hydraulic conductivity measurement of Case BLC1 during unloading stage are used (Figure 10). The sample was kept and observed under low pressure of $\pm 2 \mathrm{kPa}$ for 1 month. Measured $K$ values gradually decreasing and shows clear trend despite slight increase of void ratio (e). Although this lowering of $K$ value is small, this might be vital mechanism in order to secure and even predict the long term performance of $K$ value. Above results would seem to indicate the effect of swelling mechanism. Due to water absorption into the aggregate, void within the aggregate $\left(e_{\text {intact }}\right)$ expanded in which indicated by the increase of final water content $\left(w_{\text {final }}\right)$ (see Table 3).

As water imbibes to the clay minerals within the aggregate, spacing in-between clay parti-

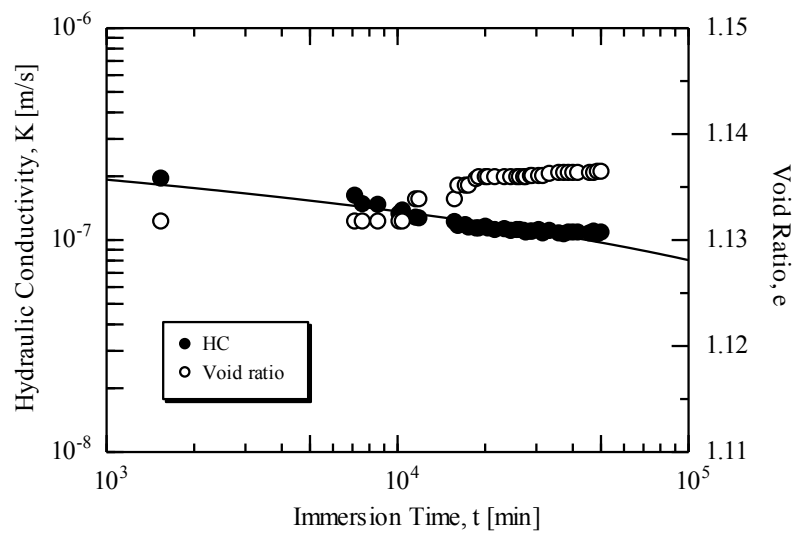

Figure 10: Observed decrease of hydraulic conductivity in ase BLC1.

Table 3: Water content measurement results.

\begin{tabular}{|c|c|c|}
\hline Test cases & $\begin{array}{c}\text { Initial water } \\
\text { content, } \\
w_{\text {init }}\end{array}$ & $\begin{array}{c}\text { Final water } \\
\text { content, } \\
w_{\text {final }}\end{array}$ \\
\hline Case BLC1 & $12 \%$ & $36-43 \%$ \\
\hline Case BLC2 & $29 \%$ & $40 \%$ \\
\hline Case GRC3 & $10 \%$ & $29-37 \%$ \\
\hline Case GRC4 & $25 \%$ & $36-37 \%$ \\
\hline Case GRC5 & $35 \%$ & $40 \%$ \\
\hline
\end{tabular}

cles began to shrink due to expansion of Dielectric Double Layer (DDL) which makes water less mobile hence decreases the $K$ values. Meanwhile, the effect of initial water content $\left(w_{\text {initial }}\right)$ can be discussed from overall results which are compiled in Figure 11. Slurry-made and remolded sample results are also plotted in the same figure as a reference. It can be said from the figure that asinitial water content increases, lower $K$ can be achieved. Table 3 shows the summarized results of both initial and final water content. After testing, the extruded sample always experienced higher water content, and those with higher initial water content will generate lower $K$ value. This suggests that alteration mechanism of the claystone from solid sedimented phase to more deformable plastic phase attributes to thelower $K$ value.

Apparently, as each aggregate transmit forces and interlocks with each other, by the help of increasing vertical pressure, water then imbibes into the aggregate, softens it, which allows it to bends or deforms within contact area hence closing the adjacent inter-aggregate pores. Wa- 


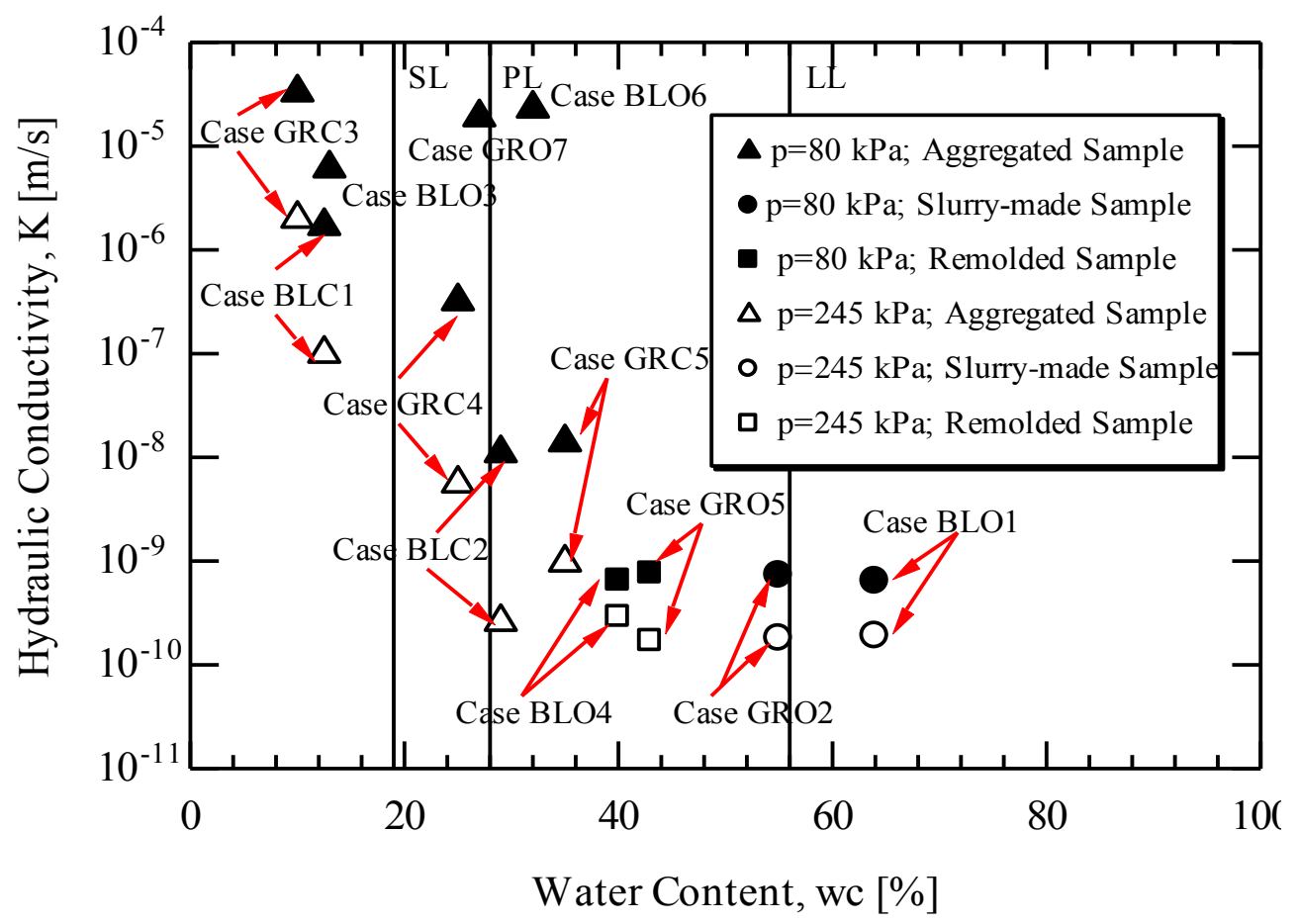

Figure 11: Effects of initial water contents on the measured hydraulic conductivities.

ter then less mobile, and that causes lower $K$ values. This mechanism can be observed from comparing results of Case BLC1 with BLC2 or Case GRC3 with GRC4-GRC5 (Figure 7). At the same void ratio, cases with higher initial water content able to generate lower $K$ values. It is appearsthat Plastic Limit (PL) to be useful indicator in order to achieve low hydraulic conductivity. $K$ values of Case $C$ are proven to achieve small enough if the samples water content arehigh enough to reach plastic conditions. The importance of proper compaction is also crucial as observed. As load increases, Case $\mathrm{C}$ able to yield $K$ values low enough to reach slurry-made and remolded samples (Figure 11; Figure 13).

\subsection{Effect of initial aggregate size gradation and gravel size fraction}

Comparison results from aggregated dry samples, Case BLO3 and Case BLC1 are presented in Figure 12. The hydraulic conductivity had decreasing trend during unloading stage for both casesbeing affected by swelling. Effective size is used to discuss the effect of initial aggregate gradation. The effective size in this studyis characterized by aggregate diameter at $10 \%$ passing $\left(d_{10}\right)$. It only logical that sample that has smaller $d_{10}$ size will generate lower $K$ values. However, Case BLC1 yields lower $K$ values compared to Case BLO3 despite larger $d_{10}$ (see Figure 4). This significant observation would seem to suggest the importance of initial aggregate gradation. Case BLC1 has wider gradation sizes than BLO3 which has less gradation with only the largest aggregate $\geq 2.36 \mathrm{~mm}$ and the smallest $\geq 0.6 \mathrm{~mm}$. Even though $d_{10}$ of BLO3 is smaller than BLC1, due to this lack of gradation, BLO3 could have higher $K$ value than BLC1 because the gradation was not enough to fill in the inter-aggregate pores at the initial state which is indicated by the large void ratio $(e)$ of Case BLO3 (see Figure 7).

Figure 13compiles all the variation of $K$ values obtained with the gravel size fraction. In this study, the gravel size fraction is defined as the aggregates retained in $4.75 \mathrm{~mm}$ sieve (USCS Standard) adopting previous studies (Shelley et al., 1993; Thai et al., 2000). From the overall results of Case $C$ show that if the samples a properly pretreated and given proper compaction effort; gravel fraction will not affect $K$ values to some extent. To achieve low $K$ value, the most important consideration is that the coarse fraction needs to be secured within the fine fraction, not in reverse, in order to prevent any migration of the fine fraction that might increase the $K$ value. Previous study show that coarse fraction does not significantly affect the $K$ value if 


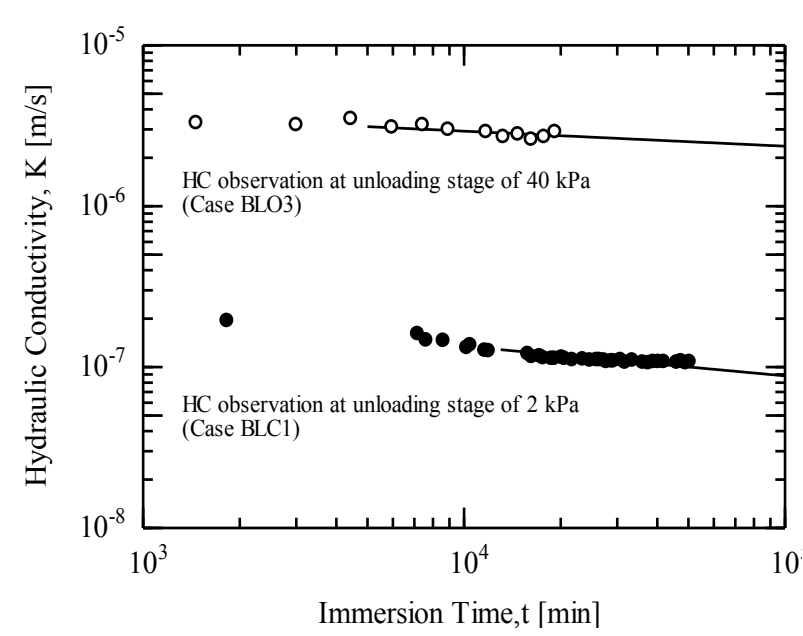

Figure 12: Long term hydraulic conductivity observation for case BLO3 and BLC1.

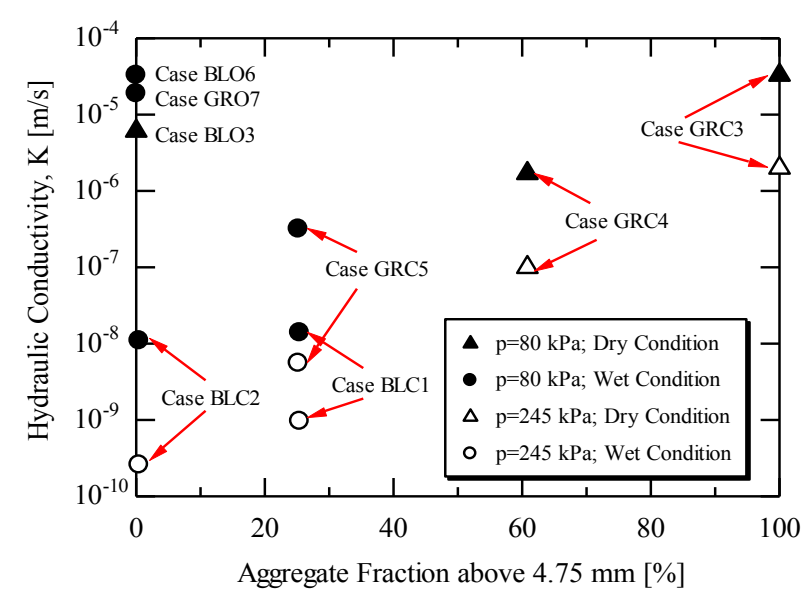

Figure 13: Hydraulic conductivity measurements based on initial gravel size fraction.

not exceeds 50-60 \% (Shelley et al., 1993; Thai et al., 2000). and fine fraction not less than $30 \%$ (Daniel, 1993). Mechanical characteristics of the material also affect the $K$ values. The $K$ value is dependent by the largest inter-aggregate pore which is highly dependent on not only aggregate size, but also rigidity and deformability of the aggregate. Rigidity will have direct impact to the ability of the aggregate crushing, so that it will able to increase fine fraction and improve the aggregate size distribution. As this particular claystone, especially highly weathered ones, will easily slake upon increase of load and water content, which are favorable factors as it application as natural barrier. It should be also noted that the small particles can be soften by absorbing water easier than the large particles.

\section{CONCLUSION}

Geological condition of study area consist of claystone intercallation with sandstone unit, claystone interbedded with sandstone unit and alluvial deposit unit. The clay mineral assemblage contained in these deposit was dominated mainly by Ca-montmorillonite, kaolinite, illite, zeolite (heulandite, mordenite), quartz, plagioclase, potassium feldspar (ortoclase and sanidine), calcite and magnetite. Hydraulic conductivity property of claystone under various treatments has been investigated through laboratory experiments. The effects of (1) swelling and initial water content, and (2) initial aggregate size distribution and large particle fraction have been observed and discussed. Aforementioned effects associated with the microlevel mechanism of the claystone which may explain the factors that contributed to the reduction of hydraulic conductivity. Practically, in order to reduce hydraulic conductivity by swelling, it is important to properly pretreat the material. Increasing the water content and maintaining the wet condition is necessary. Under wet condition, clay aggregates are able to soften and undergoform and phase alteration that enables the aggregate to acts like clods. Plastic attributes allows it to deform and close adjacent inter-aggregate pores enhancing the decrease of the $K$ values. Plastic Limit could be a convenient index to examine and predict the resultant $K$ value. In the same case, fine fraction of the utilized claystone was also important. Fine fraction needs to be larger than the coarse fraction so that coarser fraction confined securely within fines. Either by mechanically working the claystone or reducing the amount of coarse fraction is important to minimize the size of the inter-aggregate large pores, which lowers the mobility of the water, hence yield lower hydraulic conductivity values.

\section{ACKNOWLEDGMENTS}

The authors would like to give special thanks to Tokyo Institute of Technology especially Soil Mechanics and Geotechnical Engineering Group for providing apparatus and laboratory equipment for experiments. The authors very much appreciate the financial support by the research grant of Collaborative Research Pro- 
gram for Alumni Members, JICA Project for AUN/SEED-Net.

\section{REFERENCES}

Budianta, W., Prasthisto, W., Popang., M.A., Takemura, J., Hinode, H. (2014) Preliminary Study of Boyolali Clay in Central Java as Waste Disposal Liner, The International Conference on Interfaces against Pollution (IAP), May 2014, Leeuwarden, The Netherlands

Daniel, D.E. (1993) Clay Liners in Geotechnical Practice for Waste Disposal, London, Chapman \& Hall, pp. 137-163.

Yuliyanti, A., Warmada, I W., and Titisari, A.D. (2011) Characteristics and Genesis of Montmorillonitic Claystone from Bandung Area, Wonosegoro, Boyolali, Central Java, Indonesia, Journal of South East Asian Applied Geology, vol. 3, no. 1, pp. 66-71.

Pratistho, W. (2014) Geologi dan Aplikasi Lempung Wonosegoro, Boyolali Sebagai Liner Tempat Pem- buangan Akhir, Master Thesis, Department of Geological Engineering, Gadjah Mada University, (unpublished) (in Indonesian).

Tanchuling, M.A., Takemura, J., Khan, M.R.A, and Kusakabe, O. (2006) Determination of Partitioning and Dispersion Coefficient Using Column Test, Journal of the Southeast Asian Geotechnical Society, pp. 103-110.

Shelley, T.L. and D. E. Daniel (1993) Effect of Gravel on Hydraulic Conductivity of Compacted Soil Liners, Journal of Geotechnical Engineering, vol. 119 , no. 1, pp. 54-68.

Thai, N.C, Shigeyasu, A., Shoichi, K., and Takashi, H. (2000) Compaction and Permeability of Soil Containing Large Particles, Transactions of Japanese Society of Irrigation, Drainage, and Rural Engineering, vol. 208, no. 1, pp. 107-117.

van Bemmelem, R.W. (1949) The Geology of Indonesia: General Geology of Indonesia and Adjacent Archipelagoes, $2^{\text {nd }}$ ed., Vol. 1A, Martinus Nijhoff, the Haque. 